\title{
SAMUEL ROVINSKI Y EL CINE: SU OTRA PASIÓN
}

\author{
SAMUEL ROVINSKI AND HIS OTHER PASSION: THE FILM**
}

\section{María Lourdes Cortés*}

\section{RESUMEN}

Este artículo se aproxima a la actividad cinematográfica del escritor Samuel Rovinski. A su participación como fundador de Istmo Film, director y guionista en diversas obras fílmicas costarricenses, particularmente en La guerra de los filibusteros y Eulalia.

Palabras clave: Costa Rica, cine, telenovela, machismo, religión.

\begin{abstract}
The following article has the purpose of approaching Samuel Rovinski's work in the cinema. His participation in the creation of Istmo Film productions, and his works as director and scriptwriter in some of the most important Costa Rican films, specifically La guerra de los filibusteros y Eulalia.

Key Words: Costa Rica, movies, soap opera, male chauvinism, religion.
\end{abstract}


... el destino de penumbra de los escritores de cine. Nadie sabe quiénes son, a menos que sean conocidos como escritores de otra cosa, y en este caso, hasta ellos mismos tienen la tendencia a pensar que su trabajo para el cine es el secundario

(...) En realidad, el destino del escritor de cine está en la gloria secreta de la penumbra, y sólo el que se resigne a ese exilio interior tiene alguna posibilidad de sobrevivir sin amargura. Ningún trabajo exige una mayor humildad.

Gabriel García Márquez

Samuel Rovinski se enmarca en un grupo de artistas e intelectuales que se desplazan tanto en el ámbito de las letras, como del teatro y del cine. Muchos hombres y mujeres del movimiento cultural que inició entre los años 60 y 70, incursionaron de alguna forma en el cine, aún cuando éste no se había consolidado en el país. Y es que, sin duda, hay una estrecha relación entre ambas manifestaciones artísticas.

Alberto Cañas vio su obra teatral $L a$ Segua (estrenada en 1971) trasladada al cine en 1984, bajo la dirección de Antonio Yglesias. Daniel Gallegos, además de algunos guiones inéditos, escribió y dirigió un ambicioso mediometraje titulado Añoranzas del viejo Cartago (1974); Guido Sáenz, miembro activo del Teatro Arlequín en los años cincuenta y sesenta, participó como actor cinematográfico en un importante filme, La insurrección (1980), del director alemán Peter Lilienthal y produjo diversos largometrajes, siendo viceministro de cultura, en el Departamento de cine, que había fundado otra actriz del Arlequín, María de los Angeles "Kitico" Moreno.

De igual modo, Oscar Castillo, director y actor de la Compañía Nacional de Teatro pasó del arte escénico a la industria cinematográfica, para convertirse en director de cine y televisión y en el productor más fecundo del audiovisual nacional. Y con Castillo, Samuel Rovinski ingresó también de diversas maneras en el cine, con una pasión inusitada para un hombre aparentemente apacible.

\section{La creación de Istmo Film y La guerra de los filibusteros}

Como a Juan Santamaría lo empujaron a quemar el mesón, a mi también me empujaron a dirigir La guerra de los filibusteros. Yo no tengo vocación de director.

Samuel Rovinski
Durante los años setentas y ochentas, Centroamérica vivió un momento de efervescencia social, insurrecciones y muerte. La revolución sandinista y posteriormente la guerra civil frente a la Contra, en Nicaragua, así como las insurrecciones en El Salvador y Guatemala fueron acontecimientos que marcaron a toda la región. De igual manera, Panamá negoció durante esa época la soberanía de su Canal y Costa Rica, aún cuando fuera el único país con una democracia estable, no pudo aislarse del contexto regional.

De igual manera, en 1973 se había fundado el Departamento de Cine del Ministerio de Cultura, Juventud y Deportes, que había producido durante sus primeros cinco años una gran cantidad de documentales de fuerte contenido crítico a la sociedad costarricense. Títulos como Desnutrición (1973) y La cultura del guaro (1975) de Carlos Freer, Los presos (1975), de Víctor Ramírez, Las cuarenta (1975), de Víctor Vega o Costa Rica, Banana Republic (1976), de Ingo Niehaus, causaron mucha polémica en el país e incluso le costaron la cabeza a la Ministra de Cultura de entonces, la escritora Carmen Naranjo.

Para ese entonces Samuel Rovinski se encontraba en Francia, donde había realizado un año de cine en la escuela Louis Lumière. Al regresar Rovinski de Europa, junto con Oscar Castillo, Antonio Yglesias, Carmen Naranjo y Sergio Ramírez, fundaron Istmo Film, Distribuidora del Istmo y la Sala Garbo.

Estas tres empresas pretendían producir, distribuir y exhibir películas propias. Los filmes que produjeron o apoyaron durante los cinco años de existencia que tuvo Istmo Film, fueron sobre todo documentales críticos a los regímenes de la región que apoyaban los movimientos insurreccionales. Filmes como Patria libre o morir (1979) -cuyo guión es de Rovinski-, El Salvador, el pueblo vencerá (1980), La 
insurrección (1980) o Alsino y el cóndor (1982) fueron todos coproducciones de Istmo Film con los diversos países de la región. Ese compromiso de Rovinski con las realidades que se vivían en este momento, también se puede apreciar es un obra de teatro, El martirio del Pastor (1983), que fue puesta en escena por Alfredo Catania.

Dentro de la producción de Istmo Film destaca un documental de época, La guerra de los filibusteros (1981), realizado a partir de un guión de Samuel Rovinski. En 2012, a partir de esta experiencia, Rovinski publicó una crónica -originalmente escrita en 1986- titulada La ruta de los filibusteros. Rovinski relata (2012:ix):

En 1981, dos años después del triunfo del Frente Sandinista de Liberación Nacional, salí con mi equipo de cineasta de San José, Costa Rica, rumbo a Nicaragua para filmar un documental sobre el episodio de la historia de Centroamérica en el siglo XIX, que se titularía La guerra de los filibusteros.

El texto es tanto crónica de la filmación, como aguda reflexión de dos acontecimientos separados por más de un siglo: la invasión de los filibusteros en 1856, tema del documental, y el triunfo de la revolución sandinista en Nicaragua, la época en la que Rovinski realizó dicha filmación.

El documental se remonta a la invasión de Walker a Centroamérica y tiene como asunto principal la defensa de la soberanía, eje de todas las producciones de Istmo Film. Fue el piloto de una serie de diez documentales sobre la identidad centroamericana: el Popol Vuh, Francisco Morazán, la independencia e incluso algunos sobre artistas como Francisco Zuñiga y Carlos Mérida. Sin embargo, solamente La guerra de los filibusteros se concretó. La guerra en Centroamérica impidió la producción de la serie e incluso, la sobrevivencia de Istmo Film como productora y distribuidora. El grupo fundador tuvo que vender a Nicholas Baker, quien continúa exclusivamente con la Sala Garbo, como cine de arte y ensayo.

El documental de 26 minutos fue filmado tanto en Nicaragua como en Costa Rica, en lugares diversos como el río San Juan, San
Carlos, Santa Rosa, Castillo viejo, Granada y Rivas. El rodaje duró 15 días y contó con el apoyo de la Guardia Rural en Costa Rica, y de miembros del Ejército Popular Sandinista, en Nicaragua.

El filme mezcla imágenes de archivo, fotos antiguas, dibujos, un mapa de la ubicación geopolítica de los conflictos e imágenes dramatizadas de la guerra. La banda sonora destaca la voz off del narrador, así como ruidos y música que sirven para ambientar las épocas y lugares. Las imágenes dramatizadas están bien logradas y predominan los colores calientes: el amarillo del atardecer, el naranja del fuego. La fotografía fue realizada por el reconocido fotógrafo Mario Cardona.

La historia narra la lucha de los centroamericanos contra los filibusteros -germen del imperialismo yanqui- y la presencia norteamericana en la región. Además, se refiere a las transformaciones internas en la sociedad estadounidense y sus repercusiones en el área. Enfatiza, asimismo, en la importancia de la unión y solidaridad de los países centroamericanos para lograr triunfo de la defensa de su soberanía.

El filme obtuvo el III premio del Festival Internacional de Cine en Nueva York y fue contratado por el departamento de cine para la educación de la compañía Mc Graw Hill. Durante cinco años este grupo lo distribuyó en colegios, universidades y bibliotecas de Estados Unidos, lo que es un logro inédito en el país.

\section{El humor en la radiografía social}

Pretendemos una sátira humorística al melodrama que
permita, a la vez, una reflexión crítica al espectador.

Oscar Castillo

Samuel Rovinski ha evidenciado en su obra teatral y cinematográfica una mirada crítica y profunda de nuestra sociedad, utilizando especialmente la comedia.

$\mathrm{Su}$ obra más célebre y popular, Las fisgonas de Paso Ancho (estrenada en 1971) 
así y Gulliver dormido (1985), presentan esa visión crítica que tenía el autor de la sociedad costarricense, particularmente de la clase media urbana, con personajes populares reconocibles.

Las fisgonas de Paso Ancho fue un éxito rotundo y tuvo varios montajes teatrales. De igual modo, fue llevada a la televisión, por el director Alfredo Catania. Fue una serie de cuatro capítulos, presentados en Canal 7. El piloto fue transmitido el 1 de diciembre de 1989 también con gran éxito por parte de los espectadores.

De igual manera, el caricaturista costarricense Hugo Diaz intentó hacer la primera historieta del país y para ello, adaptó Las fisgonas de Paso Ancho, en1980. Pero solo se editaron tres revistas.

Ese humor crítico también fue vertido en los guiones que posteriormente realizaría el director Oscar Castillo: Eulalia (1987) y Asesinato en El Meneo (2001). Este último fue trabajado a tres manos con el mismo Castillo y con Maureen Jiménez ${ }^{1}$.

Eulalia fue un guión que Rovinski había escrito desde los tiempos de Istmo Film. Después del fracaso de público y taquilla de La Segua (1984), Castillo que había sido el productor ejecutivo, decidió realizar un filme completamente distinto: con actores, escenario y temática costarricense; en época actual y con un presupuesto bajísimo.

Castillo llamó a Rovinski y le propuso que retrabajara el guión para llevarlo a la pantalla. En un viaje a Canadá, el autor lo actualizó y Castillo consiguió el dinero para la producción.

El filme tuvo un presupuesto de 135 mil dólares, casi la cuarta parte que La Segua. Fue realizado en $16 \mathrm{~mm}$ con blow up a 35 $\mathrm{mm}$ y rodado en seis semanas, en locaciones reales, con actores profesionales y un equipo reducido de técnicos.

Sin embargo, una dirección eficiente de Castillo, un montaje ágil del mexicano Sigfrido Barjau y un guión sólido, con mucho humor y con un lenguaje muy costarricense hicieron de Eulalia la película más exitosa, en términos de crítica y taquilla, del siglo pasado.

\section{La telenovela parodiada y la fractura social}

El guión de Samuel Rovinski se propone como una sátira al melodrama, a la típica telenovela de la muchacha campesina que emigra a la ciudad, donde conoce una serie de dificultades para, finalmente, casarse con un hombre rico. Sin embargo, el filme es mucho más que eso. Carlos Cortés (2012: 3) señala:

\footnotetext{
Detrás de la película Eulalia (1987), de Oscar Castillo, en apariencia poco más que una entretenida parodia de telenovela, se oculta tanto una crítica feroz de la sociedad patriarcal como una premonición del marco ideológico en el que se entenderían las relaciones de género 25 años más tarde.
}

Eulalia es la hija mayor de un hombre de campo, Evelino, machista típico que esperaba un varón, y al que Dios lo "bendijo" con seis hembras $^{2}$. Eulalia crece y se convierte en la muchacha guapa del pueblo, perseguida por jóvenes y viejos. El padre no sabe qué hacer pues parece temer por la virginidad de la joven. Sus reacciones son desproporcionadas amenazando a los pretendientes con un largo machete en la mano y un rifle en la otra, evidentes símbolos de virilidad. Como acota certeramente Cortés (2012:3):

\footnotetext{
...no podemos dejar de temer un acre tufo a incesto reprimido asomando entre cafetos, iglesias de pueblo y estampas costumbristas.
}

Ante esto, Evelino ruega por un milagro que toma forma en la prima Yamileth, sirvienta en la ciudad, que llega a ofrecerle a Eulalia que se vaya a trabajar de niñera. Entonces, el padre decide liberarse de sus responsabilidades y manda a la joven a San José, pese a los ruegos y llantos de la madre. Rovinski acota en su guión (1985: 21).

\section{INTERIOR-DÍA. LA CASA DE ADOBE}

(...)

Yamileth toma de la mano a Eulalia y se van juntas. El jovenzuelo clava sus ojos en las caderas de la prima, que se contonea al caminar. Luzmelinda (la madre) enjuga sus lágrimas con la punta del 
delantal y se va a la cocina. Evelino se sienta en la mecedora, con el peso confortante de quien se siente liberado. El loro lo mira y chilla 'Lalita, Lalita', y la imagen se va esfumando para fundirse con el paisaje del valle central, visto desde la altura del camino de regreso de San Rafael Arriba.

Eulalia llega a la ciudad y es acosada por don Jose, el patrón y espiada por Bobby, el hijo adolescente. Yamileth, por su parte, ya había sido abusada por él, pero esto no lo vemos en el filme que se concentra en la protagonista. En el guión, se presenta ese abuso a Yamileth varias veces y cómo, ésta, lo asume con asco y resignación.

La ciudad ya ha moldeado a Yami, mucho menos ingenua que su prima. Ella quiere ser cantante y para ello está decidida a cualquier cosa, incluso a acostarse con el dueño del local o a desnudarse, como éste le pide. Yami frecuenta el salón nocturno que le "llevará a la fama" y una noche invita a Eulalia. Esta conoce a Gustavo -músico en el guión, encargado de seguridad en el filme-, quien inicia la seducción de la muchacha.

Esa misma noche, al volver a la casa, Yami es sorprendida por doña Betty, la patrona, haciendo el amor en pleno jardín. Ante el espectáculo, doña Betty expulsa a las primas. Sin embargo, Yami no se va con la cabeza baja y, por el contrario, devela el secreto familiar. El guión señala (Rovinski, 1985: 59).

\section{INTERIOR-ALBA. LA MANSION DE LOS QUIROS}

Doña Betty se despierta alarmada con el escándalo de los timbres. Mira el reloj y se frota los ojos: son las cinco de la mañana. Junto a ella, don José duerme enyesado. Doña Betty se levanta. Lo que ve la escandaliza de tal manera que no puede soltar palabra y hace aspavientos hacia don José, quien, en ese momento, se despierta y mira perpleja a su mujer.

\section{DON JOSE}

¿Qué pasa..., te volviste loca?

DOÑA BETTY (recuperando el habla) ¡Qué asco..., qué indignación! (se vuelve a asomar) En el zacate, Pepe, en mi zacate..., como perros.

DON JOSE

¿Me podés decir qué sucede?

\section{DOÑA BETTY}

(con el dorso de la mano contra la frente, a lo Sarah Bernhardt) ¡Qué inicuidad, Pepe, qué inicuidad...! (señalando hacia afuera, sin asomarse). Yami, ahí, con un hombre haciendo cochinadas... (indignada, vuelve a asomarse). Ah, pero no... esta puta no manchará la honra de nuestra casa...!

Doña Betty llama a la policia que llega pronto y pretende arrestar a la pareja por faltas a la moral (Rovinski 1985: 1961).

\section{EXTERIOR-ALBA. EL PARQUECITO}

(...)

\section{DOÑA BETTY}

Sí, oficial, lléveselos..., son unos inmorales.

\section{YAMILETH}

(Se le ha esfumado la borrachera. A doña Betty)

¿Inmorales... nosotros? Para inmoral su marido (los policías se miran entre sí, sin comprender).

\section{DOÑA BETTY}

¿Mi marido..., qué tiene que ver mi marido en esto?

\section{YAMILETH}

Usted, que habla de moral, pregúntele qué hacía cuando se cayó por la escalera... (a los policías) Se quería coger a mi prima... (a doña Betty). Primero a mí y después a mi prima..., (a los policías y la gente que mira regocijada) ¡Esos sí son inmorales...! (muy digna) ¡Qué se han creído!

\section{DOÑA BETTY}

(rabiosa) Se me van de aquí..., se me van. ¡Rameras..., mujercillas..., putas! (cierra violentamente la ventana).

La escena muestra la doble moral y la violencia de género que aún impera en el país. 
Las primas se van con el objetivo de no volver a ser sirvientas. Eulalia consigue trabajo en una pizzería y a la vez que es seducida por Gustavo conoce a don Rafael, un viejo ricachón, en envés del príncipe azul de las telenovelas. Gustavo, el típico pachuco de pantalón blanco y cadenas de oro en el cuello, la seduce, jurando por la cruz que pronto se casarán y como la lógica impone, la joven queda embarazada, Gustavo no acepta al niño y le sugiere que aborte a lo que ella se niega. Don Rafael, como "príncipe" salvador o más bien, como santo de pueblo -que es como aparece en el guión- le pide casarse y Eulalia acepta. Pero el viejo es más bien príncipe de un cuento macabro, transformándose en el más decadente y lujurioso de todos los hombres de la vida de Eulalia.

Se van de luna de miel a la playa y Eulalia descubre -aliviada- que don Rafael es impotente. No obstante, al salir con un seductor negligee, don Rafael recobra la virilidad perdida y lo único que desea es tener sexo con su mujer. El filme, por razones de censura, es más sutil en la presentación del viejo convertido en macho en celo, pero el guión ofrece una descripción mucho más escabrosa, como veremos más adelante.

Rafael Montero muere en pleno acto sexual y Eulalia se convierte en una viuda rica. En una misma escena -en el cementerio- se resume la visión de Eulalia como mujer/objeto, sexual y monetario. El muerto al descender a la fosa ve las piernas de la joven y en un último intento mortuorio, susurra con frustración el nombre de su esposa. Posteriormente, el padre que la mandó a la ciudad sin reservas, como si fuera un bulto que le estorbaba, le propone vivir con ella, no con su hija, sino con la millonaria. Finalmente, Gustavo se acerca a la mujer reclamando la paternidad del futuro bebe, el heredero.

Pero a diferencia de las telenovelas, en que el final es un matrimonio feliz con el joven apuesto, en Eulalia el cuento de hadas se ha ido fracturando reiteradamente y la mujer ha aprendido la lección. Prefiere quedarse sola que continuar siendo un cuerpo/moneda que pasa de mano en mano. Logra su autonomía y no necesita de nadie para crecer y convertirse en una madre y mujer plena.

Asimismo, como señala Cortés (2012:3)

Eulalia es uno de los mejores testimonios del cambio cultural que vivió la Costa Rica de fin de siglo. La nostalgia por las ilusiones perdidas. El cambiante presente y el indeciso porvenir.

El machismo y el abuso se han sucedido durante todo el guión/filme. Es a través de esta construcción masculina abusiva y dominante, que va del padre, al patrón, al supuesto novio $\mathrm{y}$, posteriormente al marido, donde la realidad patriarcal y la descomposición social de los años ochenta se presenta. Un momento de transición entre la Costa Rica rural de casitas de adobe, bueyes y labriegos sencillos - postal costumbrista que preveleció hasta hace muy poco- a los nuevos personajes urbanos, como el pachuco de Gustavo o el ya decadente aristócrata convertido en viejo verde.

El final del filme es un tanto ambiguo. Eulalia atraviesa la ciudad en su lujoso carro y su mirada su cruza con una familia típica: una mujer embarazada y el joven con una niña en brazos. De alguna manera, el filme intenta rescatar la idea de la familia. Una sonrisa se esboza en el rostro de Eulalia y oímos una canción de Sandra Solano que dice "Nunca más".

\section{De curas y crucifijos}

Uno de los elementos más delicados que toca el guión de Rovinski y que tuvo que ser eliminado o suavizado en el filme, es la crítica a la Iglesia católica y sus aparentes valores, asunto que en 1985 todavía no era parte de la agenda noticiosa diaria. Ya Rovinski visualizaba lo que sería, guardando las proporciones, los múltiples escándalos de abusos sexuales por miembros de la Iglesia.

Desde la época de juventud de Eulalia, entre los muchos admiradores de San Rafael Arriba, tenemos al cura del pueblo quien, mientras la confiesa, le pide detalles de las 
actuaciones de los jóvenes hacia su belleza y va imaginando a la muchacha en varias escenas eróticas. El guión explicita (Rovinski, 1985:17).

\section{INTERIOR-DIA. LA OFICINA DEL PADRE ANGELICO}

\section{$(\ldots)$}

Padre Angélico imagina a Eulalia en una sórdida zapateria, sentada en un sillón de mimbre de alto respaldo, en forma de cola de pavorreal. Una bruma tenue llena el ambiente, filtrando la luz con tonos sensuales. Eulalia viste un traje blanco, descotado, atrevidamente abierto hasta el muslo. El empleado de la zapatería, con expresión lasciva, se agacha para probarle un zapato. El movimiento la obliga a arquear la pierna y mostrar los muslos hasta donde la censura lo permita. El empleado comienza a acariciarle el pie y besárselo.

El sillón de mimbre, emblemático de la película erótica por excelencia, Emanuelle (1974) y el fetiche del zapato y el pie, utilizado en algunos filmes del cineasta Luis Buñuel, gran anticlerical confeso, toman forma en la imaginación del cura.

Posteriormente, Gustavo jura por la cruz para poder acceder a la virginidad de la joven $\mathrm{y}$, finalmente, don Rafael, que siempre aparece para Eulalia como "un santo con aureola", se convierte en un demonio bajo el crucifijo matrimonial. El guión describe minuciosamente (Rovinski, 1985: 92).

\section{INTERIOR-NOCHE. LA MANSION DE DON RAFAEL MONTERO}

En el dormitorio de los señores Montero, los postigos azotan la ventana y el viento gime. De cuando en cuando los aullidos de los perros. Una luz azulada, maligna, agrede el crucifijo sobre la cama, que cruje sin parar. El rostro de don Rafael está irreconocible: es un Baco con cuernos, lúbrico, embriagado, que despide una luz azul, montado sobre una inerme Eulalia, con los ojos abiertos, pero sin ver, como los de una santa ultrajada.

De pronto, la naturaleza hace sonar las trompetas de su autoridad. El viento deja de gemir y los perros callan. El mundo parece detenerse, al mismo tiempo que el corazón de don Rafael. Su cara pasa del supremo placer a una dolorosa y suprema estupefacción. El cuerpo se estremece en un espamo y luego queda rígido como un tronco. Los ojos parecen haber salido de sus órbitas y una mueca, entre placentera y dolorosa, desfigura su cara. Cae sobre Eulalia, con un apagado gemido y la total y absoluta rigidez de la muerte.

La luz maligna se esfuma ante el crucifijo triunfante.

Como vemos, el guión hace muchas más referencias -en un tono poco piadoso- a la Iglesia católica. Esta se muestra como parte del entramado institucional que valida el lugar del hombre-macho en nuestra sociedad. El guión la muestra como posibilitadora del abuso en varias ocasiones.

Oscar Castillo, había tenido que hipotecar su propia casa para financiar el filme. Por lo tanto, había atenuado o eliminado del filme, todos estos referentes religiosos, incluso un final más atrevido. En una entrevista realizada por Cortés (2002: 278).

Era mejor final que el que le hice. Pero cuando vos tenés tu casa hipotecada, te cuesta ser irreverente; cuando has tenido tu casa hipotecada, haz sido suficientemente irreverente. Le había 'jalado el rabo a la ternera'. Y qué hago yo con una película en la que me salga la Iglesia Católica y la censure. Hay dos Cristos en el filme en escenas paródicas. Uno yo lo había reparado pero el otro no y eso me lo reclamaron. Yo me tenía que cuidar todavía.

A partir de una parodia de telenovela, la crítica al machismo y a la falsedad de la religión como complice de una sociedad patriarcal, Rovinski prevee la paulatina autonomía que ha ido logrando la mujer costarricense. Hoy a casi 30 años de escrita, el abuso de poder de personajes como el padre, el cura, el patrón o el marido son inaceptables y, sin embargo, continúan funcionando. La relectura del guión de Rovinski permite leer no solo una sociedad en transición, sino elementos prevalentes aún en la cultura nacional.

Samuel Rovinski se involucro, como hemos visto, en diversos procesos de la industria cinematográfica: como director, como productor $\mathrm{y}$, especialmente como guionista. $\mathrm{Y}$, así como se 
le reconoce su virtud de atraer a un público masivo con su teatro, particularmente con Las fisgonas de Paso Ancho, es importante resaltar que como guionista, logró el mismo éxito, tanto en Eulalia como en Asesinato en El Meneo, presentando una crítica aguda al momento que el tocó vivir, pero en clave de humor, lo que logró que sus espectadores pudieran reflexionar y reir.

\section{Notas}

1. En vista de que este guión fue trabajado a tres manos, entre Rovinski, Castillo y Jiménez no lo trataremos en el presente estudio.

2. En el guión original, Rovinski planteaba dos varones en la familia y Eulalia y su madre eran las "sirvientas" de los varones, otra manera de mostrar el machismo, todavía imperante en nuestra sociedad.

\section{Bibliografía}

Cortés, Carlos. 2012. "Eulalia o el fin del sueño patriarcal" en La Nación (Áncora) 4 de marzo de 2012, pag. 3.

Cortés, María Lourdes. 1987. Lectura de la producción de sentido de la obra dramática de Alberto Cañas, Daniel Gallegos y Samuel Rovinski. Tesis de licenciatura. Universidad de Costa Rica.

Cortés, María Lourdes. 2002. El espejo imposible. Un siglo de cine en Costa Rica. San José: Farben Grupo Editorial Norma.

Rovinski, Samuel. 1985. Eulalia. (guión cinematográfico, inédito).

Rovinski, Samuel. 2012. La ruta de los filibusteros. San José: EUNED. 